\title{
Clinical and neurobehavioural study of the acute and chronic neurotoxicity of styrene
}

\author{
G TRIEBIG , ${ }^{1}$ S LEHRL ${ }^{2}$ D WELTLE, ${ }^{1}$ K H SCHALLER,${ }^{1}$ H VALENTIN ${ }^{1}$ \\ From the Institute of Occupational and Social Medicine and the Policlinic for Occupational Diseases, ${ }^{1}$ University \\ of Erlangen-Nürnberg, and the Department of Medical Psychology and Psychometry, ${ }^{2}$ Psychiatric Clinic, \\ D-8520 Erlangen, Federal Republic of Germany
}

\begin{abstract}
A cross sectional field study of workers exposed to styrene was performed to evaluate possible acute and chronic neurotoxic effects. A total of 36 workers of four companies handling polyester resin materials for one to 16 years (median: 7 years) and two control groups were each examined on a Monday. The control group 1 (formed to compare acute effects) consisted of 20 men from two companies with no exposure to neurotoxic chemicals. To compare chronic effects, a second control group was formed by "one to one matching" with respect to age, socioeconomic status, and pre-exposure intelligence level. Ambient air monitoring using active sampling (short time) and passive samplers (long time) showed styrene in air concentrations as follows: range 3-251 ppm (median: $18 \mathrm{ppm}$ ) and concentrations $140-600 \mathrm{ppm}$ during lamination of the inside of boats. For biological monitoring the results were as follows (postshift samples: range/median): styrene in blood: 5-482 $\mu \mathrm{g} / \mathrm{dl}(39 \mu \mathrm{g} / \mathrm{dl})$, mandelic acid urine: $0.01-3.64 \mathrm{~g} / 1(0.21 \mathrm{~g} / \mathrm{l})$, and phenylglyoxylic acid urine: $0.01-0.87 \mathrm{~g} / 1(0.19 \mathrm{~g} / 1)$. The clinical examination found no signs or symptoms of peripheral neuropathy or encephalopathy. The principal work related health complaints were acute, reversible irritation of the eyes that occurred after exposure to styrene concentrations of $200 \mathrm{ppm}$ or more. The neurobehavioural tests showed no significant differences in acute effects $(p>0.05)$ between the two groups or between preshift and postshift testing. Nor were there any significant differences in the relevant neurobehavioural variables between the styrene workers and the controls. It is concluded that occupational exposure to styrene concentrations in air up to $100 \mathrm{ppm}$ causes no adverse acute or chronic effects on the central nervous system.
\end{abstract}

Exposure to styrene occurs during lamination work in the polyester industries. ${ }^{1-3}$ To evaluate possible risks to health, many studies have been undertaken; for reviews see: Härkönen, ${ }^{4}$ DFG,${ }^{56}$ and WHO. ${ }^{7}$ To avoid adverse effects due to exposure to styrene at the workplace, in the Federal Republic of Germany maximum tolerable concentrations in air (MAKvalue) and in biological material (blood, urine) (BAT-

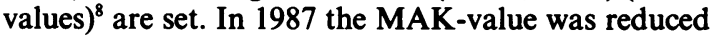
from $100 \mathrm{ppm}$ to $20 \mathrm{ppm}$, based on a re-evaluation of published neurotoxic data. ${ }^{6}$

The central nervous system seems to be a target organ for the early neurotoxic effects of relatively low concentrations of styrene. ${ }^{9-14}$ But it is not yet possible to determine the "no effect concentration" with respect to acute and chronic neurotoxic effects of occupational exposure to styrene. The main aim of the

Accepted 31 October 1988 study was, therefore, to evaluate possible effects on the central nervous system after short term and long term exposure to styrene at current workplace situations in Germany.

\section{Subjects and methods}

Three groups were included in this study.

\section{GROUP 1}

Group 1 consisted of 36 men (age: 24 to 59) in four companies with a median styrene exposure of seven years (one to 16). All the men worked in the manufacture of reinforced polyester resin products such as boats, pipes, or containers, mainly rolling the styrene containing resins. During work no respiratory masks were worn.

Besides styrene, several other solvents occurred in the working environment, including acetone, dichloromethane, toluene, xylene, heptane, methyl- 
cyclohexane, and butylacetate, but the concentrations found for these chemicals were in the range of $1 \mathrm{ppm}$ with a maximum of $5 \mathrm{ppm}$. Therefore, these solvents are not regarded as confounding factors. Ethylbenzene which is metabolised to mandelic acid (MA) and phenylglyoxylic acid (PGA) could not to be found in the air samples.

\section{GROUP 2}

Group 2 comprised 20 workers from two companies (age: 22-55) with similar professional status but without exposure to styrene or other solvents at the workplaces. Group 2 was used to compare for possible acute effects.

\section{GROUP 3}

To evaluate possible chronic effects, well known confounding factors have to be considered. ${ }^{1516}$ These are age, sex, neuropsychiatric and some other diseases such as hypertension or head injuries, professional status, alcohol and drug abuse, and the premorbid or pre-exposure intelligence level. ${ }^{17}$

Applying these criteria, 13 styrene workers had to be excluded from further evaluation of the chronic neurotoxicity. Group 3 therefore consisted of 23 men matched for age, socioeconomic status, and preexposure intelligence level who were available from an earlier study. ${ }^{18}$

The examinations were performed on a Monday before and after the workshift after an exposure free weekend; giving about 72 hours from the last exposure to styrene. The diagnostic programme was as follows: general history and specific symptoms related to the workplace, screening questionnaire for neuropsychiatric symptoms adopted from Hogstedt et al,$^{19}$ physical neurological status, neurobehavioural tests before and after the workshift, blood and urine samples for biomonitoring (styrene in blood and MA and PGA in urine) and basic laboratory parameters: blood cell count, liver enzymes (y-GT, GPT, GOT), and urine screening. Table 1 lists the neurobehavioural and psychopathometric tests. For details of the neurobehavioural test battery see elsewhere. ${ }^{17} 1820$

For the determination of styrene in blood and MA and PGA in urine a GC and HPLC method respectively was used. ${ }^{2122}$ To estimate the exposure to styrene, ambient air monitoring with passive and active sampling was performed. Diffusive samplers (ORSA 5, Drägerwerk, Lübeck) were carried for the whole shift of about seven hours. This procedure allows the determination of the time weighted exposure to styrene for the working day. Active sampling with charcoal tubes and portable pumps was performed to assess maximum styrene concentrations during lamination procedures for short time exposure. Both passive and active sampling are reliable tech-
Table 1 List of neurobehavioural and psychopathometric tests used

\begin{tabular}{|c|c|c|}
\hline Test parameter & $\begin{array}{l}\text { Unit of } \\
\text { measurement }\end{array}$ & Indicator for \\
\hline $\begin{array}{l}\text { MWT-B } \\
\text { KAI-IQ } \\
\text { KAI-KK } \\
\text { KAI-C }_{K} \\
\text { KAI-T }_{R}\end{array}$ & $\begin{array}{l}\text { IQ } \\
\text { IQ } \\
\text { bit } \\
\text { bit/s } \\
\text { s }\end{array}$ & $\begin{array}{l}\text { Level of pre-exposure intelligence } \\
\text { Level of actual intelligence } \\
\text { Capacity of short term memory } \\
\text { Speed of information processing } \\
\text { Immediate memory (apprehension } \\
\text { span) }\end{array}$ \\
\hline $\begin{array}{l}\text { KAI-C }_{\text {vw }} \\
\text { KAI-mQ } \\
\text { SRT } \\
\text { CRT }\end{array}$ & $\begin{array}{l}\mathrm{bit} / \mathrm{s} \\
\mathrm{MQ} \\
\mathrm{ms} \\
\mathrm{ms}\end{array}$ & $\begin{array}{l}\text { Basic learning speed } \\
\text { Quotient of memory } \\
\text { Simple reaction time } \\
\text { Complex reaction time }\end{array}$ \\
\hline $\begin{array}{l}\text { Defect test: } \\
\text { WES } \\
\text { SVF } \\
\text { DIS }\end{array}$ & $\begin{array}{l}\text { Raw score } \\
\text { Raw score } \\
\text { Raw score }\end{array}$ & $\begin{array}{l}\text { Alteration of personality } \\
\text { Psychovegetative symptoms } \\
\text { Dissimulation }\end{array}$ \\
\hline
\end{tabular}

niques if the well known advantages and disadvantages are taken into consideration. ${ }^{2324}$

In addition to determining the actual exposure to styrene a "chronic exposure index (CEI)" was calculated. The CEI includes years of exposure to styrene and the intensity based on AM as well as BM data of the period $1980-6$.

\begin{tabular}{|c|c|c|c|}
\hline$C E I$ & No & $\begin{array}{l}\text { Years of } \\
\text { exposure }\end{array}$ & Degree of exposure \\
\hline $\begin{array}{l}\text { C } \\
\text { D } \\
\text { E } \\
\mathbf{F} \\
\mathbf{G} \\
\mathbf{H}\end{array}$ & $\begin{array}{r}10 \\
10 \\
10 \\
8 \\
8 \\
8 \\
5 \\
5 \\
5\end{array}$ & $\begin{array}{l}<5 \\
<5 \\
<5 \\
5-10 \\
5-10 \\
5-10 \\
>10 \\
>10 \\
>10\end{array}$ & $\begin{array}{l}<50 \mathrm{ppm} \text { or MA }+\mathrm{PGA}<1000 \mathrm{mg} / \mathrm{l} \\
50-100 \mathrm{ppm} \text { or MA }+\mathrm{PGA} 1000-2000 \mathrm{mg} / \mathrm{l} \\
>100 \mathrm{ppm} \text { or MA }+\mathrm{PGA}>2000 \mathrm{mg} / \mathrm{l} \\
<50 \mathrm{ppm} \text { or MA }+\mathrm{PGA}<1000 \mathrm{mg} / \mathrm{l} \\
50-100 \mathrm{ppm} \text { or MA }+\mathrm{PGA} 1000-2000 \mathrm{mg} / \mathrm{l} \\
>100 \mathrm{ppm} \text { or MA }+\mathrm{PGA}>2000 \mathrm{mg} / \mathrm{l} \\
<50 \mathrm{ppm} \text { or MA }+\mathrm{PGA}<1000 \mathrm{mg} / 1 \\
50-100 \mathrm{ppm} \text { or MA }+\mathrm{PGA} 1000-2000 \mathrm{mg} / \mathrm{l} \\
>100 \mathrm{ppm} \text { or MA }+\mathrm{PGA}>2000 \mathrm{mg} / \mathrm{l}\end{array}$ \\
\hline
\end{tabular}

To increase the numbers of subjects on the basis of CEI for further evaluation two subgroups were formed:

Subgroup I with respect to intensity of exposure to styrene:

$1=\mathrm{A}, \mathrm{D}$, and $\mathrm{G}$ (low)

$2=\mathrm{B}, \mathrm{E}$, and $\mathrm{I}$ (medium)

$3=\mathrm{C}, \mathrm{F}$, and $\mathrm{H}$ (high)

Subgroup II with respect to duration of exposure to styrene:

$\mathrm{I}=\mathrm{A}, \mathrm{B}$, and $\mathrm{C}$ (less)

II $=\mathrm{D}, \mathrm{E}$, and $\mathrm{F}$ (medium)

III $=\mathrm{G}, \mathrm{H}$, and I (long)

For statistical analysis parametric ( $t$ test) and nonparametric (U test) tests and the $\mathrm{H}$ test according to Kruskal and Wallis were used. Because of group differences in the independent variable "premorbid intelligence" covariance analysis was used. A p value $<5 \%$ was selected as being statistically significant. 


\section{Results}

In table 2 the concentrations of styrene in the air at the four companies are shown. The former MAK-value of $100 \mathrm{ppm}$ is exceeded at eight of 36 workplaces in company $A$, whereas the present MAK value of $20 \mathrm{ppm}$ is exceeded at 18 of 36 workplaces. The highest styrene concentrations, about $600 \mathrm{ppm}$ were found during lamination work on the inside of boats or containers. Table 3 gives the results of biological monitoring. Styrene in blood was not detected in any sample before the start of work on Monday morning but small amounts of MA and PGA were, owing to the relatively long half life (about seven hours) of MA and PGA in the body. ${ }^{5}$ At the end of the workshift, styrene concentrations in blood ranged from 5 to $82 \mu \mathrm{g} / \mathrm{dl}$ (median: $39 \mu \mathrm{g} / \mathrm{dl}$ ).

Styrene concentrations in air correlate significantly with styrene in blood $(r=0.823), \mathrm{MA}$ in urine $(r=0.676)$, and PGA in urine $(r=0.845)$ in the postshift samples.

The most frequent complaints related to the workplace were, in 21 cases $(58 \%)$, acute irritations of the eyes during lamination in badly ventilated rooms. Only two controls had similar complaints. Styrene

Table 2 Styrene concentrations in air at the workplaces in the four companies, medians and range

\begin{tabular}{lccc}
\hline & \multicolumn{3}{l}{ Styrene concentration in air (ppm) } \\
\cline { 2 - 4 } Company & No & $I$ & $I I$ \\
\hline A & 12 & $136(48-251)$ & $400-600$ \\
B & 10 & $14(10-40)$ & 140 \\
D & 9 & $13(3-32)$ & 180 \\
A-D & 5 & $17(14-29)$ & $10-70$ \\
& 36 & $18(3-251)$ & $10-600$ \\
\hline
\end{tabular}

I = Time weighted average value for the whole shift (diffusion samplers).

II = Peak concentration for short time intervals during laminating work of insides of boats or containers (active sampling).

Table 3 Results of monitoring in 36 styrene workers (biological medians and ranges)

\begin{tabular}{lll}
\hline & $\begin{array}{l}\text { Time of } \\
\text { sampling }\end{array}$ & Concentration \\
\hline Styrene in blood $(\mu \mathrm{g} / \mathrm{dl})$ & A & $<1$ \\
& B & $39(5-482)$ \\
MA in urine $(\mathrm{g} / \mathrm{l})$ & A & $0 \cdot 06(0 \cdot 01-1 \cdot 66)$ \\
PGA in urine $(\mathrm{g} / \mathrm{l})$ & B & $0.21(0 \cdot 01-3.64)$ \\
MA + PGA in urine $(\mathrm{g} / \mathrm{l})$ & B & $0.05(0.01-0.85)$ \\
& A & $0.19(0.01-0.87)$ \\
& B & $0.11(0.02-1.95)$ \\
\hline
\end{tabular}

A $=$ Preshift samples

B $=$ Postshift samples.

MA = Mandelic acid.

PGA = Phenylglyoxylic acid. concentrations in air of $100 \mathrm{ppm}$ and more (time weighted average) or 200 and above as short time value caused irritation of the eyes in all workers. Prenarcotic symptoms such as dizziness, nausea, or headache during or after work were observed in four of the eight workers with the highest acute exposures (above $100 \mathrm{ppm}$ for the whole shift). Clinical examination showed no indication of a psycho-organic syndrome or of polyneuropathy either in the styrene workers or in the controls. Raised liver enzyme activities $(\gamma$-GT $>28 \mathrm{U} / \mathrm{l}$, GOT $>18 \mathrm{U} / \mathrm{l}$, GPT $>22$ $\mathrm{U} / \mathrm{l})$ were more frequent in the exposed workers than in the controls $(\gamma$-GT: $43 v 17 \%$, GOT: $13 \% v 0 \%$, GPT: $30 \% \vee 0 \%$ ). Regression analysis showed no statistically significant correlation with respect to the duration of exposure but one was found for alcohol consumption as admitted by the subjects. As mentioned above, subjects with signs of moderate or severe alcohol induced liver damage $(\gamma-\mathrm{GT}>50 \mathrm{U} / \mathrm{l})$ were excluded from further neurobehavioural assessment.

Table 4 shows the results of the neurobehavioural tests before and after the workshift. As the preexposure IQ level (MWT-B-IQ) was slightly higher for the controls it was necessary to perform a covariance analysis to check the influence on the relevant performance variables. Table 5 gives the $p$ values of the statistical comparison of the results of both groups. There are no significant differences in those parameters that might be associated with an acute psychoorganic syndrome such as KAI, simple and choice reaction time, or SVF after intra and intergroup comparison.

The results of the neurobehavioural tests which might indicate a chronic psycho-organic syndrome are shown in table 6 . No statistically significant differences were found for the two groups after controlling for non-occupational confounding factors.

Statistical calculations gave no indication of any dose effect relations when using the CEI as dose and the psychological indicators of an acute (SVF, KAI) or a chronic (WES) psycho-organic syndrome as effect (figure).

\section{Discussion}

The clinical and neurobehavioural test results in the present study may be interpreted as showing that no acute and chronic neurotoxic effects are detectable in a group basis if the styrene concentrations in the air do not exceed an average of $100 \mathrm{ppm}$ for the workshift. The conclusion is valid for the central and peripheral nervous system effects, as shown elsewhere. ${ }^{25}$

We have confirmed the effects of acute exposure to high styrene concentrations reported by other workers. ${ }^{1126-28}$

Other investigations postulate measurable neuro- 
Table 4 Results of neurobehavioural tests of acute neurotoxicity in exposed workers and controls

\begin{tabular}{|c|c|c|c|c|c|}
\hline \multirow[b]{2}{*}{ Neurobehavioural parameter } & \multirow[b]{2}{*}{ Unit } & \multicolumn{2}{|c|}{ Exposed workers $(n=36)$} & \multicolumn{2}{|c|}{ Control group $I(n=20)$} \\
\hline & & $A$ & $B$ & $A$ & $B$ \\
\hline $\begin{array}{l}\text { MWT-B-IQ } \\
\text { KAI-IQ } \\
\text { KAI-KK } \\
\text { KAI-C }{ }_{k} \\
\text { KAI-T }{ }_{R} \\
\text { SRT } \\
\text { CRT } \\
\text { Difference DRT-SRT } \\
\text { SVF } \\
\text { DIS } \\
\text { WES }\end{array}$ & $\begin{array}{l}\text { IQ } \\
\text { IQ } \\
\text { bit } \\
\text { bit/s } \\
\text { s } \\
\text { ms } \\
\text { ms } \\
\text { ms } \\
\text { Raw score } \\
\text { Raw score } \\
\text { Raw score }\end{array}$ & $\begin{array}{c}95.0(10.9) \\
101.3(12.0) \\
80.5(21.0) \\
15.5(2.5) \\
5.2(0.7) \\
306.2(50.9) \\
441.2(79.3) \\
135.1(73.4) \\
7.5(4.5) \\
9.0(3.6) \\
15.5(7.3)\end{array}$ & 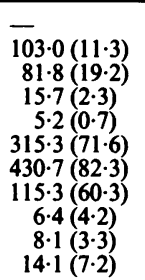 & $\begin{array}{c}98.8(10 \cdot 2) \\
107 \cdot 1(10 \cdot 8) \\
90.9(20 \cdot 3) \\
16.5(2 \cdot 4) \\
5.5(0 \cdot 7) \\
300.3(44 \cdot 0) \\
446.5(80 \cdot 7) \\
146.2(79 \cdot 2) \\
5.1(4 \cdot 6) \\
9.2(4 \cdot 5) \\
12 \cdot 1(7 \cdot 7)\end{array}$ & $\begin{array}{c}112 \cdot 1(12.3) \\
97.7(25.9) \\
17 \cdot 1(2 \cdot 8) \\
5.7(0.7) \\
298 \cdot 7(65 \cdot 5) \\
431 \cdot 3(70.0) \\
132.7(63.0) \\
4.7(4 \cdot 7) \\
9.2(4.4) \\
11.2(8.5)\end{array}$ \\
\hline
\end{tabular}

A = Preshift.

B $=$ Postshift

For abbreviations see table 1.

Table 5 Results of covariance analyses for comparison of 36 exposed workers and 20 controls

\begin{tabular}{|c|c|c|c|c|}
\hline \multirow[b]{2}{*}{$\begin{array}{l}\text { Neurobehavioural } \\
\text { parameter }\end{array}$} & \multicolumn{4}{|l|}{ p Values } \\
\hline & Preshift & Postshift & $\begin{array}{l}\text { Difference } \\
\text { pre/post } \\
\text { shift }\end{array}$ & $\begin{array}{l}\text { Difference } \\
\text { pre/post } \\
\text { shifft }\end{array}$ \\
\hline $\begin{array}{l}\text { MWT-B } \\
\text { KAI-IQ } \\
\text { KAI-KK } \\
\text { KAI-C } \\
\text { KAI-T } \\
\text { SRT } \\
\text { CRT } \\
\text { Difference }\end{array}$ & $\begin{array}{l}0.208 \\
0.085 \\
0.087 \\
0.166 \\
0.107 \\
0.667 \\
0.814\end{array}$ & $\begin{array}{l}- \\
0.008^{*} \\
0.014^{*} \\
0.056 \\
0.022^{*} \\
0.394 \\
0.977\end{array}$ & $\begin{array}{l}- \\
0.099 \\
0.078 \\
0.282 \\
0.230 \\
0.513 \\
0.830\end{array}$ & $\begin{array}{l}- \\
0.073 \\
- \\
- \\
-\end{array}$ \\
\hline $\begin{array}{l}\text { Difference } \\
\text { DRT-SRT } \\
\text { SVF } \\
\text { DIS } \\
\text { WES } \\
\text { Age }\end{array}$ & $\begin{array}{l}0.599 \\
0.063 \\
0.875 \\
0.130 \\
0.664\end{array}$ & $\begin{array}{l}0.315 \\
0.171 \\
0.356 \\
0.224 \\
-\end{array}$ & $\begin{array}{l}0.813 \\
0.166 \\
0.367 \\
0.634 \\
-\end{array}$ & $\begin{array}{l}\overline{0.357} \\
- \\
-\end{array}$ \\
\hline
\end{tabular}

*Difference significant: $p \leqslant 0.05$.

†Corrected for premorbid IQ-level (MWT-IQ).

For abbreviations see table 1 .

Table 6 Results of neurobehavioural testing (means $+S D)$ in chronic styrene exposed workers and controls matched for age, premorbid IQ-level, and socioeconomic status

\begin{tabular}{|c|c|c|c|}
\hline $\begin{array}{l}\text { Neurobehavioural } \\
\text { parameter }\end{array}$ & $\begin{array}{l}\text { Exposed } \\
(n=23)\end{array}$ & $\begin{array}{l}\text { Controls } \\
(\text { group II) } \\
(n=23)\end{array}$ & p Value \\
\hline $\begin{array}{l}\text { MWT-B-IQ } \\
\text { SVF } \\
\text { DIS } \\
\text { WES } \\
\text { Age (y) }\end{array}$ & $\begin{array}{c}96 \cdot 8(11 \cdot 3) \\
7 \cdot 8(4 \cdot 7) \\
7 \cdot 5(4 \cdot 7) \\
11 \cdot 8(8 \cdot 5) \\
39 \cdot 0(10 \cdot 8)\end{array}$ & $\begin{array}{c}99 \cdot 6(9 \cdot 8) \\
6 \cdot 7(4 \cdot 4) \\
9 \cdot 6(4 \cdot 6) \\
11 \cdot 5(5 \cdot 4) \\
39 \cdot 3(11 \cdot 0)\end{array}$ & $\begin{array}{l}0.930 \\
0.480 \\
0.149 \\
0.921 \\
0.930\end{array}$ \\
\hline
\end{tabular}

For abbreviations see table 1 .

toxic effects after exposures to $50 \mathrm{ppm}^{914}$ or below. ${ }^{29}$ Oltramare et al found prenarcotic symptoms and prolonged reaction times after exposure to $50 \mathrm{ppm}$ in three subjects ${ }^{9}$ and Mackay et al reported prolonged choice reaction times in women with postshift urinary MA-excretion of $500 \mathrm{mmol} / \mathrm{ml}$ creatinine, correspon-
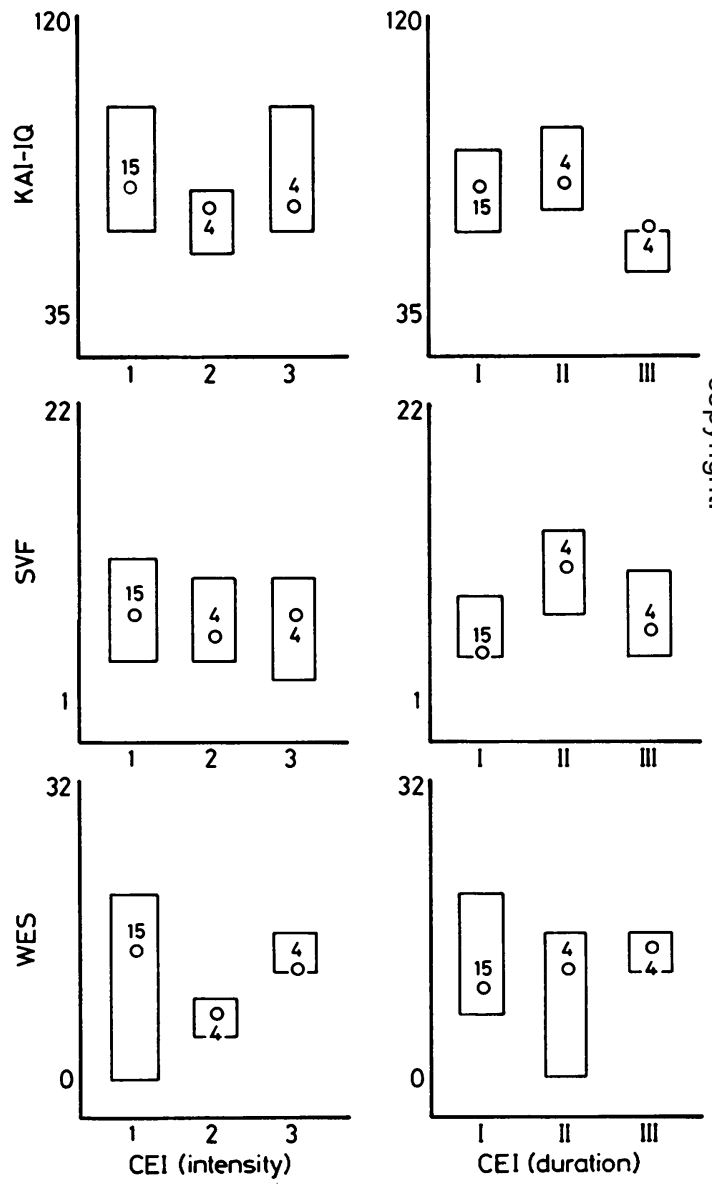

Medians ( $O)$ and central ranges (50\%) of scores of three neurobehavioural variables depending on chronic exposure index (CEI). Left figures: intensity of exposure, right figures: duration of exposure. Explanations for CEI see text and for abbreviations see table 1. 
ding to a styrene exposure of about $40 \mathrm{ppm} .{ }^{14}$ In that study no control group was used and no details of the statistical analyses given and this limits the value of the results. With regard to the chronic neurotoxic effects of styrene, only a few studies using neurobehavioural test methods have been published.

In a field study including 106 workers in the plastic boat industry Gamberale et al found longer choice reaction times in the exposed group but the longest RT times were seen in workers with the lower exposure (mean $17 \mathrm{ppm}$ ). ${ }^{28} 30$ There was no change during the night and no statistically significant differences between morning and afternoon testing were found. The postulated causal relation between exposure and reaction time, therefore, seems questionable.

Schneider and Seeber reported pathological findings in 81 workers who had "high" styrene exposure. ${ }^{10}$ Further information, especially on the levels of exposure, is missing and so no definite conclusion may be drawn from the data.

Mutti et al used various neuropsychological tests on 50 styrene exposed workers. ${ }^{13}$ The main results of this study were impaired neuropsychological function after relatively low exposure to styrene (verbal learning skills below $150 \mathrm{mmol} \mathrm{MA} / \mathrm{mol}$ creatinine; logical memory and visuomotor/constructive abilities below $300 \mathrm{mmol} \mathrm{MA} / \mathrm{mol}$ creatinine). Most of the tests were related to the same central nervous system functions and therefore the differences found were not statistically independent. Because the examinations were performed only once, on a Saturday morning, a body burden of styrene from the proceeding working days cannot be excluded. Furthermore the procedures used allowed no differentiation between acute and chronic neurotoxic effects.

With these limitations, however, this study gives some indication of the neurotoxicity of a daily exposure to styrene of concentrations of $50 \mathrm{ppm}$ and more. The deficiencies in this study might explain the differences between our results and theirs.

The lack of detectable neurotoxic effects after exposure to styrene of $100 \mathrm{ppm}$ and less reported here is in accordance with the findings of Lindström et al. ${ }^{31}$ These authors reported only slight differences between the mean values of the psychological functions of an exposed and control group. The differences were mainly caused by a subgroup with a postshift excretion of MA of more than $1762 \mathrm{mg} / \mathrm{l}$, corresponding to a mean daily exposure to styrene of 90 to $100 \mathrm{ppm}$.

In summary, published data provide little evidence that daily exposure to styrene (five days a week) in the range of 50 to $100 \mathrm{ppm}$ causes adverse effects on the central nervous system. A WHO task group concluded that "slight disturbances of visuomotor accuracy and psychomotor performance were noted at styrene levels exceeding $210 \mathrm{mg} / \mathrm{m}^{3}$ (50 ppm)".? Dick and Johnson, however, state that the " 50 ppm effect level for styrene seems unlikely", 32 this is also our view.

We are grateful to the workers and companies who participated in the study. The study was supported by grants from BASF AG, Ludwigshafen, and FranzKoelsch-Stiftung, Erlangen. We thank Dr Hoffmann for carefully reading the manuscript.

\section{References}

1 Klimkova-Deutschova E. Neurologische Befunde in der Plastikindustrie bei Styrol-Arbeitern. Internationale Archiv für Gewerbepathologie und Gewerbehygiene 1962;19:35-50.

2 Lilis R, Lorimer WV, Diamond S, Selikoff IJ. Neurotoxicity of styrene in production and polymerization workers. Environ Res 1978;15:133-8.

3 Härkönen H, Lindström K, Seppäläinen AM, Asp S, Hernberg S. Exposure-response relationship between styrene exposure and central nervous functions. Scand J Work Environ Health 1978;4:53-9.

4 Härkönen H. Styrene, its experimental and clinical toxicology. Scand J Work Environ Health 1978;4:104-13.

5 Deutsche Forschungsgemeinschaft.:Biologische ArbeitsstoffToleranz-Werte (BAT-Werte). Arbeitsmedizinisch-toxikologische Begründungen. Band 1. Weinheim: VCH-Verlagsgesellschaft, 1983.

6 Deutsche Forschungsgemeinschaft. Toxikologisch-arbeitsmedizinische Begründung von MAK-Werten. Styrol. Weinheim: VCHVerlagsgesellschaft, 1987.

7 World Health Organisation. Styrene. Geneva: WHO, 1983. (Environmental health criteria 26.)

8 Deutsche Forschungsgemeinschaft. Maximale Arbeitsplatz-Konzentrationen und Biologische Arbeitsstoff-Toleranz-Werte 1988. Weinheim: VCH-Verlagsgesellschaft, 1988.

9 Oltramare M, Desbaumes E, Imhoff C, Michiels W. Toxicologie du styrene monomere. Geneva: Editions Medecine et Hygiene, 1974.

10 Schneider H, Seeber A. Psychodiagnostik bei der Erfassung neurotoxischer Wirkungen chemischer Schadstoffe. Z Psychol 1979;187:178-205.

11 Cherry N, Waldron HA, Wells GG, Wilkinson RT, Wilson HK, Jones S. An investigation of the acute behavioural effects of styrene on factory workers. Br J Ind Med 1980;37:234-40.

12 Cherry N, Rodgers B, Venables H, Waldron HA, Wells GG. Acute behavioural effects of styrene exposure: a further analysis. $\mathrm{Br} \mathrm{J}$ Ind Med 1981;38:346-50.

13 Mutti A, Mazzucchi A, Rustichelli P, Frigeri G, Arfini G, Franchini I. Exposure-effect and exposure-response relationships between occupational exposure to styrene and neuropsychological functions. Am J Ind Med 1984;5:275-86.

14 Mackay CJ, Kelman GR. Choice reaction time in workers exposed to styrene vapour. Human Toxicol 1986;5:85-9.

15 World Health Organisation. Chronic effects of organic solvents on the central nervous system and diagnostic criteria. (Report on a Joint WHO/Nordic Council of Ministers Working Group Copenhagen, 1981.) Copenhagen: WHO, 1985. (Report No 5.)

16 Cranmer JM, Golberg L. Proceedings of the workshop on neurobehavioural effects of solvents. Neurotoxicology 1986; 7:1-123.

17 Lehrl S, Böther K, Weidenhammer W, Fischer B. Diagnose und Therapiekontrolle von organischen Psychosyndromen. Ebersberg: Vless-Verlag, 1986.

18 Triebig G, Claus D, Csuzda I, et al. Cross-sectional epidemiological study on neurotoxicity of solvents in paints and lacquers. Int Arch Occup Environ Health 1988;60:233-41. 
19 Hogstedt C, Hane M, Axelson O. Diagnostic and health care aspects of workers exposed to solvents. In: Zenz C, ed. Developments in occupational medicine. Chicago: Year Book Medical Publishers, Inc, 1980:249-58.

20 Kinzel W. Phänomenologie und Empirie seelischer Spätfolgen als Folge hirntraumatischer Verletzungen. Erlangen: Habilitationsschrift, 1975 .

21 Lewalter J, Schaller KH, Angerer J. Aromatische Carbonsäuren. In: Angerer J, Schaller KH, eds. Analytische Methoden zur Prüfung gesundheitsschädlicher Arbeitsstoffe. Band 2: Analysen im biologischen Material. Weinheim: Deutsche Forschungsgemeinschaft, VCH-Verlagsgesellschaft, 1984.

22 Will W, Zschiesche W, Goßler K, Schaller KH, Valentin H. Quantitative Bestimmung der Styrol-Metaboliten Mandelsäure und Phenylglyoxylsäure in Urin mit Hochdruck-FlüssigkeitsChromatographie und Gas-Chromatographie. Fresenius $Z$ Anal Chem 1980;303:401-5.

23 Berlin A, Brown RH, Leichnitz K, Miller B, Saunders KJ, Striefler B. Workplace air monitoring diffusive sampling - an alternative approach. In: Berlin A, Brown RH, Saunders KJ, eds. Diffusive sampling: an alternative approach to workplace air monitoring. London: Royal Society of Chemistry, 1987.

24 Triebig G, Schaller KH, Weltle D, Valentin H. Passivsammler bei arbeitsmedizinischen und arbeitshygienischen Fragestellungen.
Staub-Reinhaltung der Luft 1988;48:63-6.

25 Triebig G, Schaller KH, Valentin H. Investigations on neurotoxicity of chemical substances at the workplace. VII. Longitudinal study with determination of nerve conduction velocities in persons occupationally exposed to styrene. Int Arch Occup Environ Health 1985;56:239-47.

26 Stewart RD, Dodd HC, Baretta ED, Schaffer AW. Human exposure to styrene vapor. Arch Environ Health 1968;16:656-62.

27 Götell P, Axelson O, Lindelöf B. Field studies on human styrene exposure. Work Environ Health 1972;9:76-83.

28 Gamberale F, Hultengren M. Exposure to styrene. II. Psychological functions. Work Environ Health 1974;11:86-93.

29 Edling C, Ekberg K. No acute behavioural effects of exposure to styrene: a safe level of exposure? Br J Ind Med 1985;42:301-4.

30 Gamberale F, Lisper HO, Olson BA. The effect of styrene vapour on the reaction time of workers in the plastic boat industry. In: Horvath M, et al, eds. Adverse effects of environmental chemicals and psychotropic drugs. Amsterdam: Elsevier, 1976.

31 Lindström $\mathrm{K}$, Härkönen $\mathrm{H}$, Hernberg $\mathrm{S}$. Disturbances in psychological functions of workers occupationally exposed to styrene. Scand J Work Environ Health 1976;3:129-39.

32 Dick RB, Johnson BL. Human experimental studies. In: Annau Z, ed. Neurobehavioural toxicology. London: E Arnold Publishers Ltd, 1987. 